\title{
PENINGKATKAN HASIL BELAJAR EKONOMI DENGAN METODE DISKUSI TERBIMBING PADA SISWA KELAS XII IPS SMA NEGERI 1 BONE
}

\author{
ST.RAHMATIA \\ SMAN 1 Bone \\ e-mail: ammatia15@gmail.com
}

\begin{abstract}
ABSTRAK
Penelitian ini adalah penelitian tindakan kelas yang dilaksanakan di SMA Negeri 1 Bone dan bertujuan untuk mengetahui peningkatan hasil belajar ekonomi siswa dan aktivitas belajar dengan menggunakan metode diskusi terbimbing. Subjek penelitian adalah siswa kelas XII IPS SMA Negeri 1 Bone pada tahun pelajaran 2019/2020 yang berjumlah 30 orang dengan tingkat kemampuan dan daya serap siswa yang sangat bervariasi. Pengambilan data dilakukan dengan menggunakan tes hasil belajar dalam bentuk essay. Data yang terkumpul dianalisis dengan menggunakan analisis kuantitatif dan kualitatif. Di samping itu, untuk mengetahui keaktifan siswa dalam proses pembelajaran dengan metode diskusi terbimbing digunakan lembar observasi selama kegiatan belajar mengajar berlangsung. Hasil penelitian menunjukkan bahwa: (a) setelah diberikan tindakan dengan metode diskusi terbimbing terjadi peningkatan skor rata-rata hasil hasil belajar ekonomi siswa Kelas XII IPS SMA Negeri 1 Bone yang pada akhir Siklus I sebesar 72,40 menjadi 78,43 pada akhir Siklus II; (b) terjadi peningkatan keaktifan belajar siswa dalam proses pembelajaran dari Siklus I ke Siklus II; dan (c) berdasarkan kategori standar, perolehan skor hasil belajar ekonomi dikategorikan tinggi. Dari hasil di atas dapat disimpulkan bahwa metode diskusi terbimbing dapat meningkatkan hasil belajar ekonomi siswa Kelas XII IPS SMA Negeri 1 Bone
\end{abstract}

Kata Kunci: diskusi terbimbing, hasil belajar, aktivitas belajar

\begin{abstract}
This research is a classroom action research conducted at SMA Negeri 1 Bone and aims to determine the improvement of students' economic learning outcomes and learning activities using the guided discussion method. The research subjects were students of class XII Social Sciences at SMA Negeri 1 Bone in the 2019/2020 school year, totaling 30 people with varying levels of ability and student absorption. Data retrieval is done by using a test of learning outcomes in the form of an essay. The data collected were analyzed using quantitative and qualitative analysis. In addition, to determine the activeness of students in the learning process with the guided discussion method used observation sheets during teaching and learning activities take place. The results showed that: (a) after being given the action with the guided discussion method there was an increase in the average score of the economic learning outcomes of Class XII Social Sciences students at SMA Negeri 1 Bone which at the end of Cycle I was 72.40 to 78.43 at the end of Cycle II. ; (b) an increase in student learning activity in the learning process from Cycle I to Cycle II; and (c) based on the standard category, the score of economic learning outcomes is categorized as high. From the results above, it can be concluded that the guided discussion method can improve economic learning outcomes for Class XII Social Studies students at SMA Negeri 1 Bone
\end{abstract}

Keywords: guided discussion, learning outcomes, learning activities

\section{PENDAHULUAN}

Ekonomi merupakan bagian dari mata pelajaran ilmu pengetahuan sosial. Tujuan mempelajari Ekonomi adalah agar siswa dapat memahami apa yang terjadi di masa lampau, sehingga dapat menarik hikmah dari apa yang telah dipelajari dari peristiwa yang telah terjadi tersebut (Matroji, 2018). Kenyataan di lapangan menunjukkan bahwa dalam proses pembelajaran Ekonomi siswa terlihat kurang antusias, daya kreativitasnya rendah, dan siswa 
bersikap acuh tak acuh. Sebabnya mungkin karena guru kurang menguasai materi dan strategi pembelajarannya kurang tepat sehingga kurang memiliki daya dukung

Dalam rangka meningkatkan hasil belajar Ekonomi kiranya diperlukan strategi pembelajaran yang tepat serta metode pembelajaran yang bervariasi. Metode pembelajaran bervariasi adalah pemanfaatan berbagai macam metode pembelajaran dalam proses belajar mengajar. Salah satunya, yakni penggunaan metode diskusi yang dibimbing langsung oleh guru secara lebih mendalam. Dengan pembelajaran seperti ini siswa akan memperoleh pemahaman yang mendalam dari kejadian-kejadian yang lebih luas. Bahkan nilai-nilai yang dapat dipetik oleh para siswa dalam peristiwa tersebut juga dapat dicapai dengan baik. Sebab belajar Ekonomi pada hakekatnya adalah belajar dari pengalaman masa lampau untuk kepentingan masa sekarang (Mustafa Shodiq, 2009)

Melalui penggunaan metode diskusi terbimbing diharapkan para siswa Kelas XII IPS dapat memahami cara berdiskusi dengan bimbingan guru. Dalam metode diskusi terbimbing dapat melatih siswa tentang keterampilan mengajukan pertanyaan, keterampilan menjawab pertanyaan, sikap menghargai pendapat orang lain, kerjasama baik antara sesame kelompok maupun dari kelompok lain, kemampuan memecahkan masalah, kemampuan menarik kesimpulan dan lain- lain. Metode diskusi terbimbing merupakan proses komunikasi dua arah dengan cara memberikan kesempatan kepada dua belah pihak untuk dapat mencurahkan perasaan secara lebih terbuka sehingga memberikan peluang untuk berkembangnya ide-ide dari seluruh siswa yang terlibat dan berpartisipasi didalamnya secara lebih bebas (Herlina, 2020).

Berdasarkan pengalaman penulis sebagai pengajar di Kelas XII IPS, hasil belajar Ekonomi siswa Kelas XII IPS SMA Negeri 1 Bone sangat rendah, yang diakibatkan oleh pelaksanaan pembelajaran dengan menggunakan metode ceramah atau siswa menjadi tidak aktif. Nilai rata-rata hasil belajar dari hasil ujian adalah 6,5. Kondisi di atas tentu sangat memprihatinkan. Untuk memperbaiki dan meningkatkan hasil belajar siswa Kelas XII IPS tersebut, banyak cara yang harus dilakukan. Untuk keperluan ini maka akan dicoba melalui penggunaan metode pembelajaran. Adapun salah satu metode dalam pembelajaran tersebut adalah diskusi terbimbing.

\section{METODE PENELITIAN}

Penelitian ini merupakan jenis penelitian tindakan kelas (Classroom Action Research) model Kemmis dan Taggart (Arikunto, 2013) yang dilaksanakan dalam 2 siklus. Tindakan yang dilakukan adalah pembelajaran dengan metode diskusi terbimbing melalui tahapan-tahapan perencanaan (Planning), tindakan (Action), observasi (Observation), dan refleksi (Reflection). Penelitian ini dilaksanakan pada siswa kelas XII IPS SMA Negeri 1 Bone semester genap tahun ajaran 2020/2021, dengan jumlah siswa 28 orang yang terdiri dari 30 orang yang terdiri 24 perempuan dan 6 laki-laki. Variabel dalam penelitian ini terdiri atas dua variabel yaitu variabel input adalah pengajaran Ekonomi melalui pembelajaran dengan metode diskusi terbimbing dan variabel output adalah hasil belajar Ekonomi. Dalam instrumen penelitian ini yang digunakan berupa lembar observasi, angket dan tes hasil belajar Ekonomi.

Adapun teknik pengumpulan data yang di lakukan dalam penelitian tindakan kelas ini adalah: (1). Data tentang keaktifan peserta didik dan guru tentang metode pembelajaran diskusi terbimbing yang dilakukan selama proses pembelajaran berlangsung dalam tindakan diambil dengan menggunakan lembar observasi. (2).Data mengenai hasil belajar Ekonomi peserta yang diajar dengan menerapkan metode pembelajaran diskusi terbimbing diperoleh dengan memberikan tes pada setiap akhir siklus. Pada siklus I jumlah soal yang diberikan 5 soal sedangkan pada siklus II jumlah soal yang diberikan juga 5 soal. (3).Data tentang tanggapan peserta didik tentang metode pembelajaran diskusi terbimbing yang dilakukan selama proses pembelajaran berlangsung diambil dengan menggunakan angket yang diberikan setelah akhir siklus I dan siklus II. 


\section{HASIL DAN PEMBAHASAN}

Hasil

Secara umum gambaran hasil penelitian yang telah dilaksanakan selama siklus I dan Siklus II adalah sebagai berikut:

Tabel 1. Kategori aktivitas belajar siswa siklus I dan Siklus II

\begin{tabular}{|c|c|c|c|c|c|}
\hline \multirow{2}{*}{$\begin{array}{c}\text { Rentang } \\
\text { Skor }\end{array}$} & \multirow{2}{*}{ Kategori } & \multicolumn{2}{|c|}{ Frekuensi } & \multicolumn{2}{c|}{ Persen } \\
\cline { 3 - 6 } $0-7$ & Siklus I & Siklus II & Siklus I & Siklus II \\
\hline $8-14$ & $\begin{array}{c}\text { Sangat } \\
\text { Kurang }\end{array}$ & 0 & 0 & 0.00 & 0.00 \\
\hline $15-21$ & Kurang & 1 & 0 & 3.33 & 0.00 \\
\hline $22-28$ & Sedang & 14 & 2 & 46.67 & 6.67 \\
\hline $29-35$ & Baik & 15 & 19 & 50.00 & 63.33 \\
\hline \multicolumn{2}{|c|}{ Jumlah Baik } & 0 & 9 & 0.00 & 30.00 \\
\hline
\end{tabular}

Berdasarkan tabel di atas terdapat perbedaan aktivitas belajar siswa pada siklus I dan Siklus II, meskipun peningkatan aktivitas belajar siswa tidak terlalu mencolok. Akan tetapi dengan perubahan persentase keaktifan siswa dapat disimpulkan bahwa dengan penerapan metode diskusi terbimbing maka motivasi siswa dalam memperhatikan pelajaran lebih meningkat.

Tabel 2. Hasil belajar dalam persen dan kategori siklus I dan Siklus II

\begin{tabular}{|c|c|c|c|c|c|}
\hline \multirow{2}{*}{ Rentang Nilai } & \multirow{2}{*}{ Kategori } & \multicolumn{2}{|c|}{ Frekuensi } & \multicolumn{2}{c|}{ Persen } \\
\cline { 3 - 6 } & Siklus I & Siklus II & Siklus I & Siklus II \\
\hline $00-64$ & Tidak Tuntas & 6 & 0 & 20.00 & 0.00 \\
\hline $65-69$ & Tuntas Rendah & 4 & 3 & 13.33 & 10.00 \\
\hline $70-79$ & Tuntas Sedang & 12 & 12 & 40.00 & 40.00 \\
\hline $80-89$ & Tuntas Tinggi & 8 & 14 & 26.67 & 46.67 \\
\hline $90-100$ & $\begin{array}{c}\text { Tuntas Sangat } \\
\text { Tinggi }\end{array}$ & 0 & 1 & 0.00 & 3.33 \\
\hline \multicolumn{2}{|c|}{ Jumlah } & 30 & 30 & 100 & 100 \\
\hline
\end{tabular}

Berdasarkan tabel di atas terdapat peningkatan hasil belajar siswa dari siklus I ke siklus II, dimana pada siklus I masih terdapat beberapa orang yang belum tuntas. Sedangkan pada siklus II semua siswa memperoleh nilai tuntas. Meskipun nilai ketuntasan masih ada yang tergolong rendah dan sedang. Secara umum ketuntasan hasil belajar siswa digambarkan pada grafik berikut:

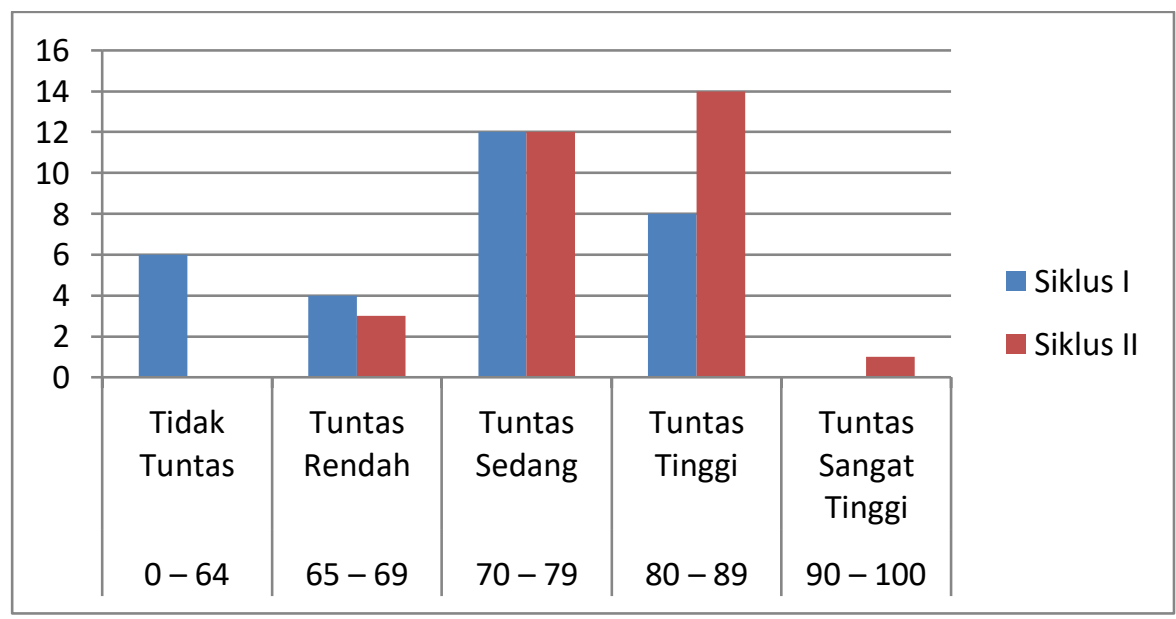

Gambar 1. Grafik aktivitas belajar siswa Siklus I 


\section{Pembahasan}

Hasil tindakan siklus I sebagai kontribusi dari penggunaan model pembelajaran diskusi terbimbing dalam proses pembelajaran memberikan dampak yang cukup berarti dalam perubahan aktivitas belajar siswa ke arah yang lebih baik. Perubahan itu telah mencapai hasil dengan cenderung berada pada kategori sedang. Secara keseluruhan aktivitas belajar siswa ada kecenderungan sudah baik tetapi masih ada 13 orang siswa (43,33 persen) yang belum menunjukkan perubahan yang berarti. Kelemahan yang paling menonjol terletak pada keaktifan siswa mengajukan pertanyaan, menjawab pertanyaan dan menghagai pendapat orang lain. Artinya, proses tindakan yang dilaksanakan guru belum mampu membangkitkan inisiatif siswa dalam menemukan ide-ide atau motivasinya belum berkembang. Pembelajaran belum mampu meningkatkan kerja siswa secara sistematis dalam melaksanakan diskusi dengan baik.

Pembelajaran yang belum memberikan perubahan yang berarti pada aktivitas belajar pada dasarnya diakibatkan oleh aktivitas mengajar guru yang belum optimal. Kekurangan yang paling mendasar terletak pada belum optimalnya upaya guru membangkitkan antusiasme dan kreativitas belajar siswa, akibatnya hasil belajar yang dicapai belum memuaskan. Penguasaan konsep atau hasil belajar belum memuaskan. Hal ini dibuktikan dengan masih adanya 6 orang siswa (20,00 persen) yang belum berhasil mencapai KKM. Belum maksimalnya penguasaan konsep diakibatkan oleh kemampuan menalar yang masih serba terbatas, sehingga perlu adanya proses penyajian materi yang lebih sistematis dan contoh yang lebih kongkret. Selain itu perlu adanya bimbingan kepada siswa yang masih mengalami kesulitan.

Alternatif pemecahan masalah adalah perlunya guru menerapkan model pembelajaran diskusi terbimbing harus diawali dengan memantapkan pengetahuan prasyarat, kemudian perlu penyampaian langkah- langkah pelaksanaan diskusi dengan tepat. Upaya tersebut perlu diiringi perencanaan pembelajaran yang lebih sistematis. Hasil tindakan siklus II sebagai kontribusi dari penggunaan metode pembelajaran diskusi terbimbing adalah terjadinya perubahan aktivitas belajar siswa yang sangat signifikan. Perubahan yang terjadi sangat signifikan sehingga indikator keberhasilan yang telah ditetapkan pada aspek aktivitas belajar sudah tercapai.

Secara keseluruhan aktivitas belajar siswa ada kecenderungan sudah baik dan telah terjadi perubahan yang signifikan, tetapi walau pun demikian masih perlu ditingkatkan. Masih terdapat beberapa siswa yang aktivitas belajarnya belum optimal terutama pada aspek "berinisiatif dan kerja sistematis". Artinya, tindakan yang dilaksanakan guru perlu dioptimalkan melalui variasi mengajar agar inisiatif siswa dalam menemukan dan mengemukakan ide-ide dalam pemecahan masalah dapat meningkat. Selain itu kemampuan kerja siswa secara sistematis dalam menyelesaikan soal belum optimal. Pembelajaran pada dasarnya telah memberikan perubahan yang berarti pada peningkatan perilaku positif dalam belajar. Tetapi penulis menginginkan terwujudnya perilaku positif yang optimal. Disadari bahwa untuk memenuhi hasrat tersebut bukan pekerjaan yang mudah karena harus berbanding lurus dengan peningkatan aktivitas mengajar dalam menerapkan suatu metode atau pun strategi.

Kekurangan yang masih ada pada siklus II ini diupayakan dapat teratasi pada siklus berikutnya. Artinya penerapan metode pembelajaran diskusi terbimbing perlu ditambah dengan variasi lain agar inisiatif siswa dapat meningkat dalam setiap kegiatan belajar. Peningkatan inisiatif dan kreativitas belajar siswa, diharapkan dapat meningkatkan hasil belajar. Walau pun telah terjadi peningkatan hasil belajar secara signifikan dalam pencapaian kriteria ketuntasan minimal tetapi masih ada 10,00 persen ( 3 siswa) yang hasil belajarnya berada pada kategori tuntas rendah. Belum maksimalnya penguasaan konsep diakibatkan oleh kemampuan menalar yang masih serba terbatas, sehingga perlu adanya variasi proses penyajian materi yang lebih sistematis dan contoh menyelesaikan soal penerapan. Selain itu masih perlu adanya bimbingan kepada siswa yang masih mengalami kesulitan baik dari guru atau siswa lain yang sudah memiliki kemampuan lebih baik.

Alternatif pemecahan masalah adalah perlunya guru menerapkan metode pembelajaran diskusi terbimbing secara sistematis yang dikolaborasi dengan kompetisi antar kelompok. Tujuannya adalah untuk memicu inisiatif dan kinerja siswa secara progresif. Upaya tersebut 
perlu diiringi dengan perencanaan pembelajaran yang lebih sistematis dan menantang. Penerapan metode pembelajaran diskusi terbimbing bertujuan untuk membuat proses pembelajaran menjadi efektif dan menyenangkan, selain menekankan pada hasil yang dicapai, juga metode yang digunakan cenderung berorientasi pada keaktifan siswa (Muhammad Nur, 2000). Penerapan metode tersebut bertujuan untuk perbaikan mutu pembelajaran yang memberikan kesempatan kepada siswa untuk lebih aktif dan lebih memberikan kesempatan untuk menyalurkan kemampuan masing- masing secara langsung baik individu maupun kelompok untuk digunakan dalam memecahkan masalah. Setelah tindakan dilaksanakan dari siklus I hingga siklus II, penerapan metode pembelajaran diskusi terbimbing telah menciptakan iklim belajar menjadi lebih baik dari sebelumnya. Perubahan secara signifikan terjadi setelah metode pembelajaran diskusi terbimbing dikolaborasi dengan teknik pembelajaran langsung.

Keunggulan yang diperoleh melalui penerapan strategi pembelajaran tersebut. Keunggulan yang paling mendasar (Trianto, 2007) adalah:

1. Meningkatkan kemampuan berpikir sendiri, memberi informasi kepada teman sejawat dan meningkatkan kepercayaan diri bagi setiap siswa, dan dapat belajar dari siswa yang lain

2. Meningkatkan kemampuan mengungkapkan ide atau gagasan secara verbal dan membandingkannya dengan ide-ide siswa lainnya

3. Membantu memberdayakan siswa untuk lebih bertanggung jawab dalam belajar

4. Meningkatkan hasil akademik, kemampuan sosial, mengembagkan rasa harga diri, hubungan interpersonal yang positif, meningkatkan keterampilan mengatur waktu, dan sikap positif terhadap pembelajaran di sekolah.

Aktivitas belajar positif yang dimiliki siswa memegang peranan penting dalam meningkatkan hasil belajar akademiknya. Apa yang dialami siswa dalam proses pembelajaran memberikan pengalaman yang sangat berarti dalam mengkonstruksi pengetahuan yang diterima. Pengetahuan yang dimiliki berupa konsep atau formula menjadi siap pakai untuk memecahkan masalah Ekonomi yang berhubungan dengan konsep tersebut. Siswa tidak hanya memiliki keterampilan menyelesaikan soal tetapi mereka memiliki pengetahuan yang dapat digunakan pada setiap saat jika dibutuhkan (Djamrah \& Bahri, 2000). Penerapan metode pembelajaran diskusi terbimbing mempersyaratkan kemampuan guru dalam merancang persiapan pembelajaran, terutama pembuatan makalah yang memiliki karakteristik yang dapat mengembangkan daya nalar untuk menyelidiki dan menemukan konsep. Penemuan inilah yang menjadi kontribusi terpenting bagi siswa karena pengetahuan itu mereka miliki, bukan hanya sekedar mengenalnya.

Kombinasi penggunaan metode pembelajaran diskusi terbimbing dan pembelajaran langsung memberikan warna tersendiri dalam proses, karena siswa diberikan kesempatan bersosialisasi, membagi tugas dan tanggung jawab dan yang terpenting mereka bekerja sama untuk saling mengisi untuk mengatasi kekurangan masing-masing. Hasil pembelajaran dengan menggunakan metode tersebut tampak pada perubahan aktivitas belajar dari siklus satu ke siklus berikutnya, baik secara klasikal maupun secara individual. Pada siklus I, aktivitas belajar siswa mencapai rerata 21,36; meningkat pada siklus II mencapai rerata 26,63. Fakta tersebut mengimplikasikan bahwa peningkatan aktivitas belajar siswa tidak lain adalah sebagai akibat dari semakin baiknya proses pembelajaran yang dilaksanakan guru di kelas.

Beberapa penelitian terbaru tentang penerapan metode diskusi terbimbing menyimpulkan bahwa terjadi peningkatan hasil belajar setelah penerapan metode tersebut. Penelitian itu antara lain oleh (Herlina, 2020) Melalui penelitian dengan judul "Penggunaan Metode Diskusi Kelompok Terbimbing dalam Upaya Meningkatkan Hasil Belajar Geografi pada Siswa SMAN 1 Cisarua Kabupaten Bandung Barat”, Kemudian oleh (Mas'ad, 2019) dengan judul "Efektivitas Metode Pembelajaran Guided Note Taking Dan Metode Diskusi Terbimbing Terhadap Hasil Belajar Ips Terpadu Siswa Kelas VIII Mts". Kemudian oleh (Bungalangan, 2020) dengan judul penelitian "Penerapan Metode Diskusi Terbimbing dalam Meningkatkan Hasil Belajar IPS Siswa Kelas VI SD Negeri 1 Hongoa Kabupaten Konawe”. 


\section{KESIMPULAN}

Berdasarkan hasil penelitian dan pembahasan dapat ditarik kesimpulan sebagai berikut:

1. Penggunaan metode pembelajaran diskusi terbimbing dalam pembelajaran dapat meningkatkan aktivitas belajar siswa dalam pembelajaran Ekonomi di Kelas XII IPS SMA Negeri 1 Bone.

2. Penggunaan metode pembelajaran diskusi terbimbing dalam pembelajaran dapat meningkatkan hasil belajar Ekonomi siswa di Kelas XII IPS SMA Negeri 1 Bone.

\section{DAFTAR PUSTAKA}

Arikunto, S. (2013). Prosedur penelitian suatu pendekatan praktik hellis.litbang.kemkes.go.id. Bungalangan, Y. T. (2020). Penerapan Metode Diskusi Terbimbing dalam Meningkatkan Hasil Belajar IPS Siswa Kelas VI SD Negeri 1 Hongoa Kabupaten Konawe. Jurnal Profesi Keguruan, 6(2), 190-197.

Djamrah, \& Bahri, S. (2000). Guru dan Anak Didik Dalam Interaksi Edukatif. Rineka Cipta.

Herlina, E. (2020). Penggunaan Metode Diskusi Kelompok Terbimbing dalam Upaya Meningkatkan Hasil Belajar Geografi pada Siswa SMAN 1 Cisarua Kabupaten Bandung Barat. Universal Journal of Educational Research, 1(1), 1-11.

Mas'ad, K. (2019). Efektivitas Metode Pembelajaran Guided Note Taking Dan Metode Diskusi Terbimbing Terhadap Hasil Belajar Ips Terpadu Siswa Kelas Viii Mts. 7(1), 28-33.

Matroji. (2018). Ekonomi 2 SMA/MA. Bumi Aksara.

Muhammad Nur. (2000). Pengajaran berpusat Kepada siswa dan Pendekatan Konstruktivis dalam pengajaran. Universitas Negeri Surabaya.

Mustafa Shodiq. (2009). Wawasan Ekonomi 2 Indonesia dan Dunia untuk Kelas XI SMA dan MA Program IPS. Tiga Serangkai.

Trianto. (2007). Model- model Pembelajaran Inovatif Berorientasi Konstruktif. Prestasi Pustaka Publisher. 